\title{
Comparison of heavy-metal bioaccumulation properties in Pinus sp. and Quercus sp. in selected European Cu deposits
}

\author{
Peter Andráśs ${ }^{1,2}$, Ingrid Turisová ${ }^{1}$, Giuseppe Buccheri ${ }^{1}$, João Manuel Xavier de Matos $^{3}$, and \\ Vojtech Dirner ${ }^{2}$ \\ ${ }^{1}$ Faculty of Natural Sciences, Matej Bel University, Banská Bystrica, Slovakia \\ ${ }^{2}$ VŠB - Technical University Ostrava, Ostrava - Poruba, Czech Republic \\ ${ }^{3}$ Laboratório Nacional de Energia e Geologia, Beja, Portugal \\ Correspondence to: Peter Andráš (peter.andras@umb.sk)
}

Received: 1 October 2015 - Revised: 25 February 2016 - Accepted: 1 March 2016 - Published: 12 April 2016

\begin{abstract}
Heavy-metal contamination of Pinus pinaster, P. sylvestris, Quercus robur, and Q. rotundifolium was studied in four abandoned historic $\mathrm{Cu}$ deposits from Italy (Libiola, Caporciano), Portugal (São Domingos), and Slovakia (L'ubietová). The highest $\mathrm{Cu}$ and $\mathrm{Mn}$ contents in anthropogenic soil were described in Libiola and Caporciano whereas the highest $\mathrm{Pb}, \mathrm{Zn}, \mathrm{As}$, and $\mathrm{Sb}$ contents in São Domingos. The anthropogenic soil in L'ubietová shows the highest Co contents. The area of São Domingos is the most acidified. There are important differences between the bioaccumulation of plants from individual deposits. Bioavailability of the heavy metals is generally independent of the $\mathrm{pH}$ values. The high $\mathrm{Ca}$ and $\mathrm{Mg}$ contents in soil are able to block the transport of heavy metals to the plant tissues. The bioconcentration factor values of all plant taxa, in all deposits, indicate a predominant strategy of excluders. Only Ag shows excellent bioconcentration ability. In L'ubietová, Pinus sylvestris has a strategy as an accumulator of $\mathrm{Pb}$ (2.43) and $\mathrm{Zn}$ (2.49); Pinus pinaster of $\mathrm{Mn}$ (4.97), $\mathrm{Cd}$ (1.85), and Co (5.62) and Quercus rotundifolium of Mn (3.54) in São Domingos. The predominantly low translocation factor values indicate that in most cases the heavy metals are accumulated in roots; only in a few rare cases do they migrate to shoots (e.g. $\mathrm{Zn}$ in Pinus sp. from all localities, Co in P. pinaster in São Domingos).
\end{abstract}

\section{Introduction}

Mine dump fields are the specific habitats, because they have specific ecological conditions, which limit plant growth. Mainly, it is deficiency of soil substrate, nutrients, and water. The soils are rocky, strongly skeletal with deficiency or absence of humus layer, and have increased content of heavy metals in soils naturally rich in their content. The long-term influence of the stress factors caused, in the case of some plants, physiological and genetical tolerance necessary for their survival (Viehweger, 2014). It is a global evolution strategy (Herrera-Estrella et al., 1999; Ramírez-Rodríguez et al., 2007). This adaptation from metallotolerant ecotypes to genotypes is well known from heavy-metal tolerance evolution (MacNair and Baker, 1994), and their direct utilization is applied in phytoremediation. Many authors study the ac- cumulation of metals in plants as the results of this study have practical importance for bioindication, biomonitoring, and phytoremediation (e.g. Remon et al., 2013; Kleckerová and Dočekalová, 2014; Paz-Ferreiro et al., 2014; Stefanowicz et al., 2015).

The transfer and accumulation of the heavy metals into the plant organs is usually substantially influenced by various factors: primarily by heavy-metal content in soil and by soil characteristics (e.g. the mould and clay minerals content), by soil reaction, by cation exchange capacity, or by $\mathrm{Ca} / \mathrm{Mg}$ content ratio (Kavamura and Esposito, 2010; Fijalkowski et al., 2012; Čurlík et al., 2015). The effect of $\mathrm{pH}$ on the metal mobility is a variable but very important factor (Alkorta et al., 2004; Vamerali et al., 2010). Mobility of metals in soils with low $\mathrm{pH}$ decreases in the order $\mathrm{Cd}>\mathrm{Ni}>\mathrm{Zn}>\mathrm{Mn}>\mathrm{Cu}>\mathrm{Pb}$ (Vamerali et al., 2010). Highly contaminated sites are usu- 


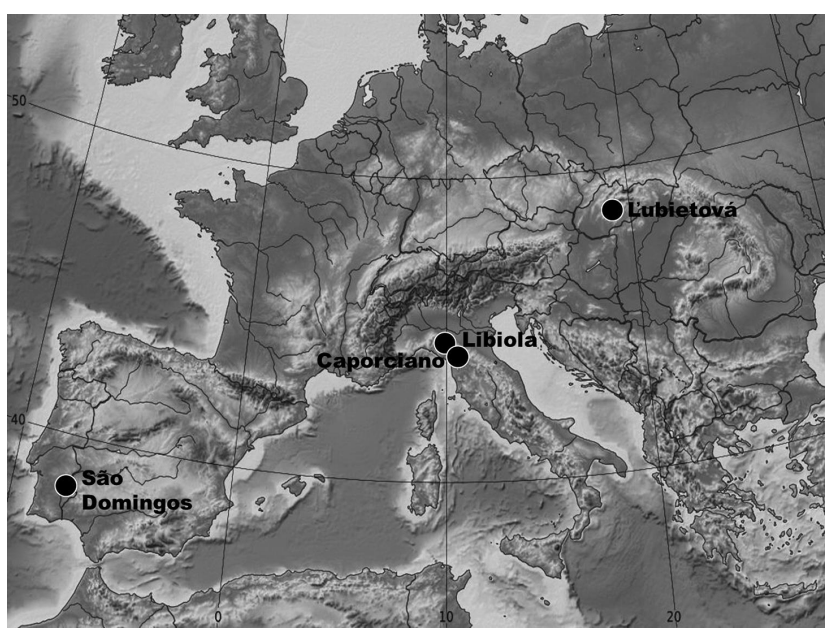

Figure 1. Localization of the studied deposits.

ally poor in organic matter content. Organic matter can work as a factor which causes heavy-metal release but also can immobilize heavy metals. This is the reason for the use of recycled organics in agriculture, forestry, and mine rehabilitation (Kelly, 2008).

The potential of oxidation reduction of soil significantly determines participation in the form of a mobile element, which can enter the biological cycle, in relation to the total element content. Lack of oxygen in the soil causes start-up and increases the mobility of the large part of heavy metals (Kavamura and Esposito, 2010).

Also forms of heavy-metal occurrence in soil significantly affect their mobility. The most mobile elements are $\mathrm{Cd}, \mathrm{Zn}$, and $\mathrm{Mo}$, while the least mobile are $\mathrm{Cr}, \mathrm{Ni}$, and $\mathrm{Pb}$ (Prasad and Freitas, 2003). Our study also pointed out the Mn high mobility.

Uptake and accumulation of selected metals is primarily dependent on the plant species, its inherent controls, and the soil quality (Chunilall et al., 2005).

Four abandoned $\mathrm{Cu}$ deposits having historical importance in Europe were compared (Fig. 1). First data about the heavymetal contamination of plants in L'ubietová are discussed by Andráš et al. (2007). Information about the heavy-metal contamination of some plants in Libiola and Caporciano is presented by Buccheri et al. (2014) and Dadová et al. (2015), and in area of São Domingos mining district was studied by numerous authors (Freitas et al., 2004; Abreu and Magalhães, 2009; Abreu et al., 2012).

Among the plants identified in the study areas we focused on some autochthon-related species and simultaneously dominant pioneer trees with relatively high coverage that can be compared to each other with respect to their bioconcentration properties. These are the same strategies regarding the colonization of mining heap, with the same role in the process of spontaneous succession. They belong to two genera - Pinus and Quercus. Each is represented by two species: Pinus sylvestris L. and Quercus robur L. in Slovakia, Pinus pinaster Aiton and Quercus rotundifolia Lam. in Italy and Portugal. This paper addresses the following questions:

i. Is there a negative correlation between soil acidity and bioavailability of heavy metals in the investigated species?

ii. Is the heavy-metal input to plants influenced by $\mathrm{Ca}$ and $\mathrm{Mg}$ content or by $\mathrm{Ca} / \mathrm{Mg}$ ratio in sorption complex?

iii. Are the bioaccumulation characteristics of these dominant pioneer trees similar and usable in remediation?

\section{Material and methods}

\subsection{Subjects of scientific studies}

L'ubietová (Slovakia) was one of the most important mining areas in central Europe during the Middle Ages. The $\mathrm{Cu}$ content in the ore ranged from 4 to $10 \%$, and the $\mathrm{Ag}$ content was about $70 \mathrm{~g} \mathrm{t}^{-1}$ (Andráš et al., 2012; Kharbish et al., 2014). In 500 years about $25000 \mathrm{t}$ of copper was produced. The mining activities were finished at the end of the 19th century (Ilavský et al., 1994).

The stratiform Libiola deposit is situated at the western border of northern Apennines mountains in Gromolo stream valley near Sestri Levante (Liguria, Italy). The Caporciano near Montecatini Val di Cecina (Tuscany, Italy) was the most important European $\mathrm{Cu}$ deposit during the 19th century. The exploitation finished in 1907, and the mine was closed (Orlandi, 2006). During the last mining activity $30000 \mathrm{t}$ of copper was exploited. Both Libiola and Caporciano had been exploited since Etruscan times.

São Domingos (Baixo Alentejo province, Portugal) was exploited even in pre-Roman times. The deposit belongs to the most important massive $\mathrm{Cu}$ mineralization of massive pyrite-chalcopyrite metallogenic province in the Iberian Pyrite Belt, where the resources of the ore are estimated at about 1700 Mt (Sáez et al., 1999). The mining ended by 1966 (Matos et al., 2010).

\subsection{Data sampling and analysis}

During the growing season in 2012 (in Slovakia), 2013 (in Portugal), and 2014 (in Italy) 15 plant samples were taken (separately roots, branches, leaves/needles, bore out of the tree trunk at a height of $1 \mathrm{~m}$ respectively just below the treetops) and 15 soil samples from their root ball from a depth up to $10 \mathrm{~cm}$ from every species and every locality. The soil and plant samples were dried at laboratory temperature. The individual parts of the plants were analysed separately. The average value was calculated for all species at each of the four localities. The values of heavy-metal content in shoots were calculated as the average of values of single above-ground plant parts. 

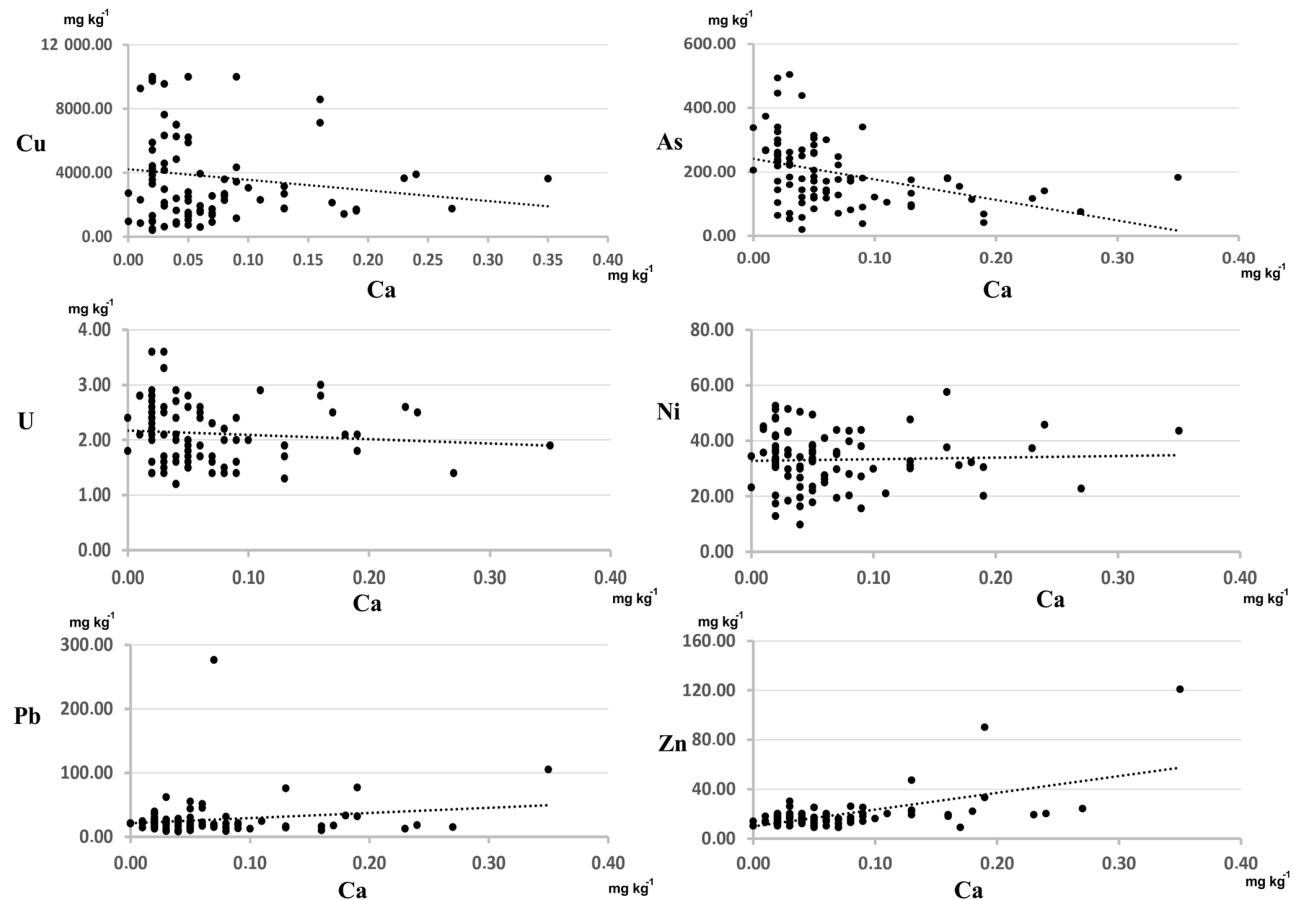

Figure 2. Relation of Ca vs. heavy-metal content $(\mathrm{Cu}, \mathrm{As}, \mathrm{U}, \mathrm{Ni}, \mathrm{Pb}, \mathrm{Zn})$ in Pinus sylvestris from L'ubietová.

Both the soil and plant samples were analysed by ICP-MS in ACME Laboratories in Vancouver, Canada. The rinse and paste $\mathrm{pH}$ of soil was measured according to the methodology by VanReeuwijk (1995) and calculated for standard hydrogen electrode. Rinse and paste $\mathrm{pH}$ was in soil samples measured according to Sobek et al. (1978).

As two important parameters for assessing input and accumulation of heavy metal by plants are bioconcentration factor (BCF) and translocation factor (TF). BCFs were calculated following Eq. (1) according to Mehes-Smith et al. (2013) and TF according to Singh et al. (2010) following Eq. (2):

$\mathrm{BCF}=$ content of heavy metal in shoots / content of heavy

metal in corresponding soil $\left(\mathrm{mg} \mathrm{kg}^{-1}\right)$,

$\mathrm{TF}=$ content of heavy metal in shoots / content of heavy

metal in corresponding roots $\left(\mathrm{mg} \mathrm{kg}^{-1}\right)$.

If the $\mathrm{BCF}<1$, the plant is an excluder; if $\mathrm{BCF}=1$, the plant is an indicator. If the $\mathrm{BCF}>1$, the plant is an accumulator to hyperaccumulator (Baker, 1981).

Correlation coefficients were calculated using the Statgraphics Centurion XVI, version 16.1.11 (32 bit; StatPoint Technologies Inc., USA, 2010).

\section{Results and discussion}

Calcium is usually accumulated (contrawise to $\mathrm{Mg}$ ) in upper horizons and is better soluble; thus it is better bioavailable as
Mg (Verbruggen and Hermans, 2013). The high Mg content has generally phytotoxic impact on plants, because it inhibits the $\mathrm{Ca}$ and $\mathrm{K}$ input (Gunes et al., 1998; Brady et al., 2005; Alexander et al., 2007; Merhaut, 2007).

The heavy-metal input to plants is influenced by $\mathrm{Ca}$ and $\mathrm{Mg}$ content or by $\mathrm{Ca} / \mathrm{Mg}$ ratio in sorption complex in deposits L'ubietová, Caporciano, and São Domingos. There was observed inhibition of $\mathrm{Cu}$, As, and $\mathrm{U}$ by $\mathrm{Ca}$ in Pinus sylvestris in L'ubietová. This trend was not found in the case of $\mathrm{Ni}, \mathrm{Pb}$, and $\mathrm{Zn}$ (Fig. 2). In Libiola calcium content does not inhibit the transport of the metals to plant organs of Pinus pinaster (Fig. 3). In São Domingos the average $\mathrm{Ca}$ content is $0.51 \%$ and of $\mathrm{Mg} 0.31 \%$; the $\mathrm{Ca} / \mathrm{Mg}$ ratio in soil $=1.645$ and the element pair shows positive correlation. Such a $\mathrm{Ca} / \mathrm{Mg}>1$ ratio is generally characteristic of basic rocks (McCarten, 1992). The high Ca content inhibits some heavy metals $(\mathrm{Cu}, \mathrm{Pb}, \mathrm{Ag}, \mathrm{As})$ input to Pinus pinaster (Fig. 4).

Hydrogen ion activity $(\mathrm{pH})$ is probably the most important factor governing metal speciation, solubility from mineral surfaces, transport, and bioavailability of metals in aqueous solutions (John and Leventhal, 1995). Typically, the adsorption of metals increases from near zero to near $100 \%$ as $\mathrm{pH}$ increases through a critical range $1-2$ units wide. This means that a relatively small shift in $\mathrm{pH}$ in surface water causes a sharp increase or decrease in the concentration of a dissolved metal (Salomons, 1995). A certain degree of negative correlation between acidity $(\mathrm{pH})$ and BCF was proved only in São Domingos in Pinus pinaster in the case of Mn (correlation 

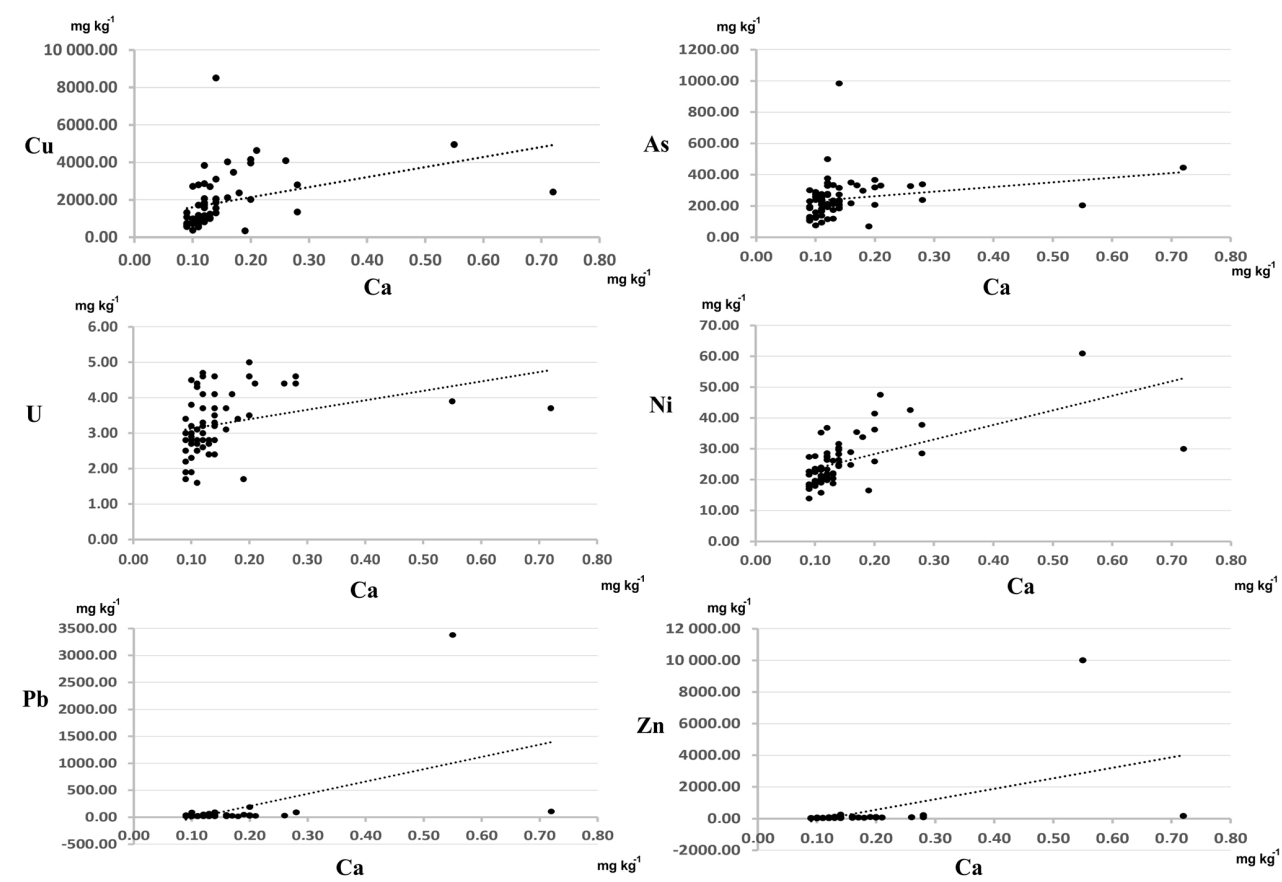

Figure 3. Relation of Ca vs. heavy-metal content $(\mathrm{Cu}, \mathrm{As}, \mathrm{U}, \mathrm{Ni}, \mathrm{Pb}, \mathrm{Zn})$ in Pinus pinaster from Libiola.
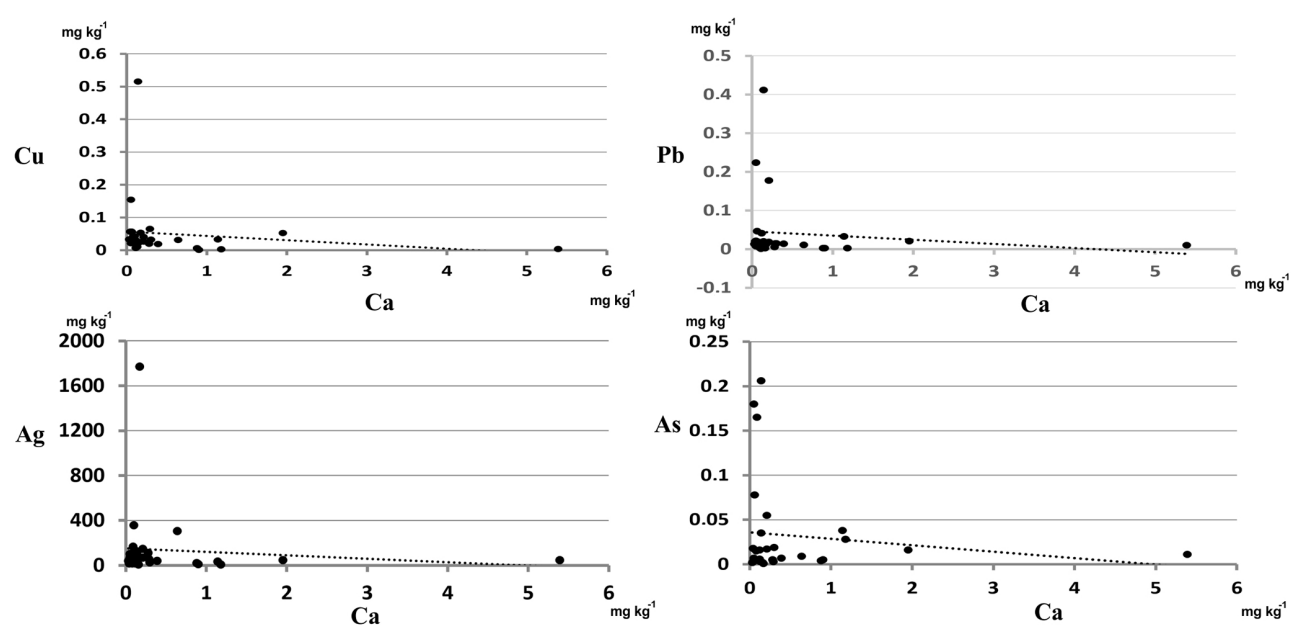

Figure 4. Relation of Ca vs. heavy-metal content $(\mathrm{Cu}, \mathrm{Pb}, \mathrm{Ag}, \mathrm{As})$ in Pinus pinaster from São Domingos.

coefficient $r=-0.307), \mathrm{Zn}(r=0.251)$, and $\mathrm{Cd}(r=0.219$; Fig. 5). In the case of $\mathrm{Cu}$, this relation was not observed. A similarly high influence of $\mathrm{pH}$ in heavy-metal absorption was confirmed, for example, in Amaranthus retroflexus L. (Khoramnejadian and Saeb, 2015).

There are important differences between the bioaccumulation of plants from individual deposits. The BCF values of all plant taxa, from the studied deposits, indicate a strategy of excluders, especially in the case of oaks. This means there are no suitable species for phytoextraction. They could be used only in the process of phytostabilization, since heavy metals accumulate preferentially in their roots. A similar effect was confirmed also in Picea abies (L.) H. Karst. and Populus tremula $\mathrm{L}$., which were exposed long-term to metalcontaminated soils (Brunner et al., 2008). Only Ag shows excellent bioconcentration ability (Table 1), especially in Pinus pinaster $(\mathrm{BCF}=57.51-73.75)$ and Quercus rotundifolium $(\mathrm{BCF}=43.79 ; 66.59)$. In L'ubietová, Pinus sylvestris has a strategy of an accumulator of $\mathrm{Pb}$ and $\mathrm{Zn}$. While the zinc is translocated into leaves ( $\mathrm{TF}=2.95), \mathrm{Pb}$ is fixed in roots $(\mathrm{TF}=0.18)$. The translocation of $\mathrm{Zn}$ is often restricted due to the ability of this element to create zinc-phytochelatin 

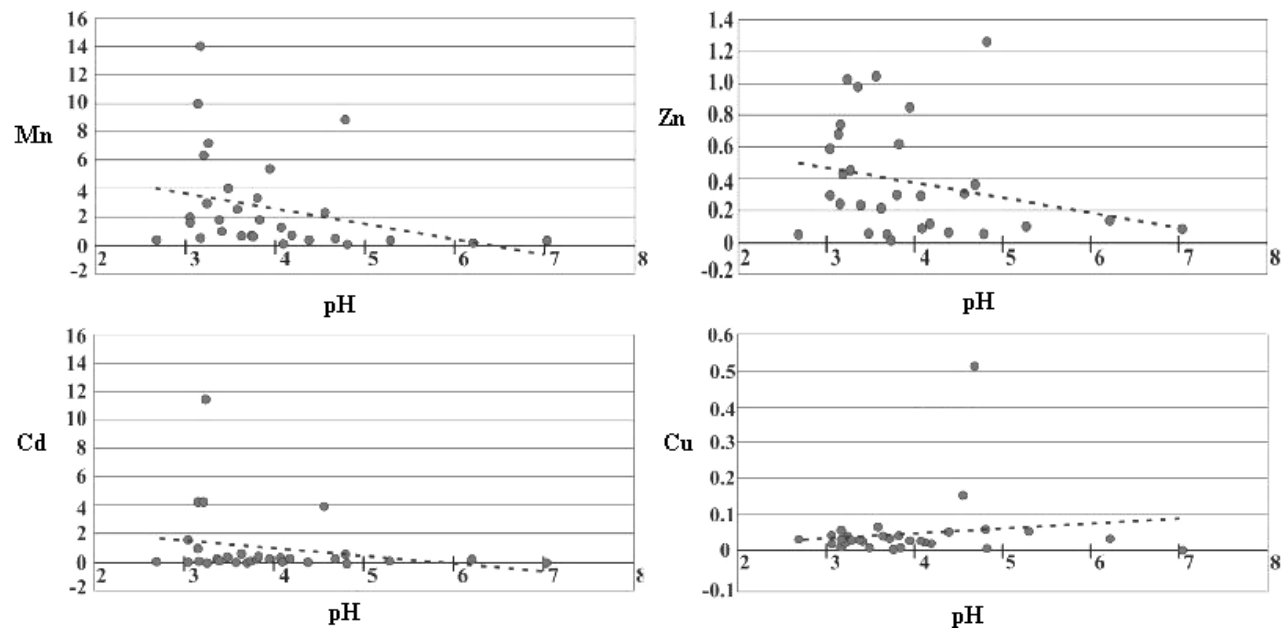

Figure 5. Correlation between $\mathrm{pH}$ and $\mathrm{BCF}$ of $\mathrm{Mn}, \mathrm{Zn}, \mathrm{Cd}$, and $\mathrm{Cu}$ (in $\mathrm{mg} \mathrm{kg}^{-1}$ ) in Pinus pinaster from São Domingos.

Table 1. Bioconcentration factor and translocation factor calculated for plants from studied localities.

\begin{tabular}{|c|c|c|c|c|c|c|c|c|c|c|c|c|}
\hline \multirow[t]{2}{*}{ Deposit } & \multirow[t]{2}{*}{ Plant taxa } & $\mathrm{Fe}$ & $\mathrm{Mn}$ & $\mathrm{Cu}$ & $\mathrm{Zn}$ & $\mathrm{Pb}$ & $\mathrm{Ag}$ & $\mathrm{Cd}$ & $\mathrm{Ni}$ & $\mathrm{Co}$ & As & $\mathrm{Sb}$ \\
\hline & & \multicolumn{11}{|c|}{ Bioconcentration factor } \\
\hline \multirow[t]{2}{*}{ L'ubietová } & Pinus sylvestris & 0.010 & 0.11 & 0.27 & 2.22 & 1.60 & 5.00 & 1.00 & 0.00 & 0.05 & 0.00 & 0.00 \\
\hline & Quercus robur & 0.000 & 0.17 & 0.16 & 0.51 & 1.19 & 18.93 & 0.60 & 0.12 & 0.02 & 0.00 & 0.00 \\
\hline Libiola & Pinus pinaster & 0.002 & 0.12 & 0.01 & 0.68 & 0.02 & 66.36 & 0.69 & 0.01 & 0.04 & 0.01 & 0.02 \\
\hline \multirow[t]{2}{*}{ Caporciano } & Pinus pinaster & 0.002 & 0.07 & 0.01 & 0.29 & 0.04 & 73.75 & 0.45 & 0.01 & 0.02 & 0.05 & 0.01 \\
\hline & Quercus rotundifolium & 0.006 & 0.14 & 0.01 & 0.08 & 0.05 & 66.59 & 0.07 & 0.03 & 0.15 & 0.52 & 0.34 \\
\hline \multirow[t]{3}{*}{ São Domingos } & Pinus pinaster & 0.003 & 4.97 & 0.01 & 0.42 & 0.01 & 57.51 & 1.85 & 0.24 & 5.62 & 0.01 & 0.00 \\
\hline & Quercus rotundifolium & 0.004 & 3.54 & 0.24 & 0.41 & 0.01 & 43.79 & 0.27 & 0.16 & 0.11 & 0.01 & 0.01 \\
\hline & & \multicolumn{11}{|c|}{ Translocation factor } \\
\hline \multirow[t]{2}{*}{ L'ubietová } & Pinus sylvestris & 0.940 & 1.01 & 2.14 & 2.95 & 0.18 & 11.43 & 3.33 & 1.81 & 1.09 & 0.36 & 0.08 \\
\hline & Quercus robur & 0.770 & 0.99 & 0.87 & 0.50 & 0.50 & 0.75 & 0.60 & 0.31 & 0.29 & 1.54 & 0.44 \\
\hline Libiola & Pinus pinaster & 0.170 & 1.01 & 0.18 & 1.06 & 0.14 & 0.23 & 0.20 & 3.75 & 0.31 & 0.09 & 0.06 \\
\hline \multirow[t]{2}{*}{ Caporciano } & Pinus pinaster & 0.590 & 4.26 & 0.19 & 2.37 & 1.46 & 1.59 & 0.67 & 1.00 & 1.75 & 1.00 & 0.36 \\
\hline & Quercus rotundifolium & 0.400 & 3.82 & 0.11 & 1.36 & 0.94 & 2.29 & 0.23 & 1.27 & 3.60 & 1.00 & 1.94 \\
\hline \multirow[t]{2}{*}{ São Domingos } & Pinus pinaster & 0.103 & 5.20 & 0.14 & 2.49 & 0.11 & 0.45 & 0.70 & 0.67 & 16.38 & 0.23 & 0.30 \\
\hline & Quercus rotundifolium & 0.300 & 5.56 & 0.21 & 1.36 & 0.32 & 0.45 & 0.41 & 0.99 & 0.51 & 0.45 & 0.10 \\
\hline
\end{tabular}

complex by sequestration in the vacuole (Lux et al., 2011). $\mathrm{Mn}, \mathrm{Cd}$, and Co are accumulated by Pinus pinaster in São Domingos. This is shown by various bioaccumulative properties of these two species.

The predominantly low TF values indicate also that in most cases the heavy metals are accumulated in the roots, which is known in many other scientific studies (Tamás and Kovács, 2005; Tomaškin et al., 2013; Parzych, 2016). Only in a few rare cases do they migrate to shoots (Andráš et al., 2013), e.g. Mn and $\mathrm{Zn}$ in all species (accepted Quercus robur), and Co in Pinus pinaster $(\mathrm{TF}=16.38)$ in São Domingos.

\section{Conclusions}

Obtained results show various pictures that are dependent on the object and the type of rock formations. Different plant species and even the same plant species at different localities show very variable results of bioavailability for individual metals. Bioavailability of the heavy metals is at the studied localities generally independent of the $\mathrm{pH}$ values. The studied areas are poor in organic matter content. The high $\mathrm{Ca}$ and $\mathrm{Mg}$ contents in soil are able to block the transport of heavy metals to the plant tissues. Most of the plants are excluders $(\mathrm{BCF}<1)$ for individual elements. Only Ag shows 
excellent bioconcentration ability. Also BCF data for Pinus sylvestris from L'ubietová reflect moderate bioavailability of $\mathrm{Pb}$ and $\mathrm{Zn}$ and migration of $\mathrm{Zn}$ predominantly to the needles (at all localities). In the rest of the plants, the metals are accumulated in roots, with few exceptions. None of the studied plant species are suitable for phytoextraction. As the localities are strongly contaminated by heavy metals and their area has great extent, the only possible phytoremediation method is phytostabilization. Finding the suitable plant for such a solution will be the aim of the next study.

Author contributions. Peter Andráš and Ingrid Turisová designed the aims of the research work and of the experiments; they also prepared the article with contributions from all co-authors. Giuseppe Buccheri (Italy) and João Manuel Xavier de Matos (Portugal) helped with the recognition of the terrain and with the field work, and Vojtech Dirner provided the laboratory work and helped with the evaluation of the obtained analytical results.

Acknowledgements. The work was supported by grant scheme APVV-0663-10 and VEGA 1/0538/15.

Edited by: J. Guiot

\section{References}

Abreu, M. M. and Magalhães, M. C. F.: Phytostabilization of soils in mining areas. Case studies from Portugal, in: Soil Remediation, Nova Science Publishers, New York, USA, 297-344, 2009.

Abreu, M. M., Santos, E. S., Magalhães, M. C. F., and Batistaet, M. J.: São Domingos mine wastes phytostabilization using spontaneous plant species, in: 9th International Symposium on Environmental Geochemistry, Aveiro, Portugal, 15-21 July, 42-49, 2012.

Alexander, E. B., Coleman, R. G., Keeler-Wolf, T., and Harrison, S.: Serpentine Geoecology of Western North America: Geology, Soils, and Vegetation, Oxford University Press, New York, USA, 528 pp., 2007.

Alkorta, I., Hernandez-Alica, J., Becerril, J. M., Amezaga, I., Albizu, I., and Garbisu, C.: Recent findings on the phytoremediation of soils contaminated with environmentally toxic heavy metals and metalloids such as zinc, cadmium, lead and arsenic, Rev. Environ. Sci. Biotechnol., 3, 71-90, 2004.

Andráš, P., Turisová, I., Šlesárová, A., and Lichý, A.: Influence of the dump sites on development of selected plants in the L'ubietová area (Slovakia), Carpath. J. Earth. Env., 2, 5-20, 2007.

Andráš, P., Nagyová, I., Samešová, D., and Melichová, Z.: Study of environmental risks at an old spoil dump field, Pol. J. Environ. Stud., 21, 1529-1538, 2012.

Andráš, P., Dirner, V., Kharbish, S., and Krnáč, J.: Characteristics of heavy metal distribution at spoil dump-fields of $\mathrm{Cu}$-deposit L'ubietová (Slovakia), Carpath. J. Earth. Env., 8, 87-96, 2013.

Baker, A. J. M.: Accumulators and excluders, J. Plant. Nutr., 3, 643654, 1981.
Brady, K. U., Kruckeberg, A. R., and Bradshaw Jr., H. D.: Evolutionary Ecology of Plant Adaptation to Serpentine Soils, Annu. Rev. Ecol. Evol. Syst., 36, 243-266, 2005.

Brunner, I., Luster, J., Günthardt-Goerg, M. S., and Frey, B.: Heavy metal accumulation and phytostabilisation potential of tree fine roots in a contaminated soil, Environ. Pollut., 152, 559-568, 2008.

Buccheri, G., Andráš, P., Andráš Jr., P., Dadová, J., and Kupka, J.: Heavy metal contamination and its impact on plants at $\mathrm{Ca}-$ porciano Cu-mine (Montecatini Val di Cecina, Italy), Carpath. J. Earth. Env., 9, 73-81, 2014.

Chunilall, V., Kindness, A., and Jonnalagadda, S. B.: Heavy metal uptake by two edible Amaranthus herbs grown on soils contaminated with lead, mercury, cadmium, and nickel, J. Environ. Sci. Health B, 40, 375-384, 2005.

Čurlík, J., Kolesár, M., Ďurža, O., and Hiller, E.: Dandelion (Taraxacum officinale) and Agrimony (Agrimonia eupatoria) as Indicators of Geogenic Contamination of Flysch Soils in Eastern Slovakia, Arch. Environ. Con. Tox., Epub 9 August 2015, doi:10.1007/s00244-015-0206-z, 2015.

Dadová, J., Buccheri, G., and Midula, P.: Heavy metal pollution of environment in area of abandoned $\mathrm{Cu}$-mines Libiola and Caporciano, LAP Lambert Academic Publishing, Stuttgart, Germany, 83 pp., 2015.

Fijalkowski, K., Kacprzak, M., Grobelak, A., and Placek, A.: The influence of selected soil parameters on the mobility of heavy metals in soils, Inžynieria i Ochrana Šrodowiska, 15, 81-92, 2012.

Freitas, H., Prasad, M. N. V., and Pratas, J.: Plant community tolerance and trace elements growing on the degraded soils Portugal: environmental implications, Environ. Int., 30, 65-72, 2004.

Gunes, A., Alpaslan, M., and Inal, A.: Critical nutrient concentrations and antagonistic and synergistic relationships among the nutrients of NFT-grown young tomato plants, J. Plant Nutr., 21, 2035-2047, 1998.

Herrera-Estrella, L., Guevara-García, A., and López-Bucio, J.: Heavy metal adaptation. Encyclopedia of Life Science Macmillian Publishers, London, UK, 1-5, 1999.

Ilavský, J., Vozárová, A., and Vozár, J.: L’ubietová - štruktúrnovyhl'adávacie vrty LU-1, Lu-2 a Lu-3, Geologický ústav Dionýza Štúra, Bratislava, Slovakia, 77 pp., 1994.

John, D. A. and Leventhal, J. S.: Bioavailability of metals, Chapter 2, in: Preliminary compilation of descriptive geoenvironmental mineral deposit models, U.S. Department of the interior U.S. geological survey Open-File Report 95-831, Denver, Colorado, USA, 10-18, 1995.

Kavamura, V. N. and Esposito, E.: Biotechnological strategies applied to the decontamination of soils polluted with heavy metals, Biotechnol. Adv., 28, 61-69, 2010.

Kelly, G.: Application of recycled organics in mine site rehabilitation. Department of Environment and Climate Change NSW, Sydney, Australia, 37 pp., 2008.

Kharbish, S., Andráš, P., Luptáková, J., and Milovská, S.: Raman spectra of oriented and non-oriented $\mathrm{Cu}$ hydroxy-phosphate minerals: libethenite, cornetite, pseudomalachite, reichenbachite and ludjibaite, Spectrochim. Acta A, 130, 152-163, 2014.

Khoramnejadian, S. and Saeb, K.: Accumulation and Translocation of Heavy Metals by Amaranthus retroflexus, J. Earth. Environ. Health Sci., 1, 58-60, 2015. 
Kleckerová, A. and Dočekalová, H.: Dandelion Plants as a Biomonitor of Urban Area Contamination by Heavy Metals, Int. J. Environ. Res., 8, 157-164, 2014.

Lux, A., Martinka, M., Vaculík, M., and White, P. J.: Root responses to cadmium in the rhizosphere: a review, J. Exp. Bot., 62, 21-37, 2011.

MacNair, M. R. and Baker, A. J. M.: Metal-tolerant plants: an evolutionary perspective, in: Plants and Chemical Elements: Biochemistry, Uptake, Tolerance and Toxicity, VCH, Weinheim, Germany, 67-85, 1994.

Matos, J. X., Pereira, Z., Fernandes, P., Rosa, D., and Oliveira, J. T.: Contribuição para estudo da estrutura da mina de Aljustrel (Faixa Piritosa Ibérica) com base em novos dados palinoestratigráficos do Complexo Vulcano-Sedimentar e da Fm. Mértola, eTerra, VIII Congresso Nacional de Geologia, 21, 4 pp., 2010.

McCarten, N.: Community structure and habitat relations in a serpentine grassland in California, in: The vegetation of ultramafic serpentine soils, Proceeding of the First International Conference on Serpentine Ecology, University of California, Davis, Intercept, Hampshire, USA, 207-211, 1992.

Mehes-Smith, M., Nkongolo, K. K., Narendrula, R., and Cholewa, E.: Mobility of heavy metals in plants and soil: a case study from a mining region in Canada, Amer. J. Environ. Sci., 9, 483-493, 2013.

Merhaut, D. J.: Magnesium, in: Handbook of Plant Nutrition, Taylor and Francis Group, Boca Raton, USA, 145-181, 2007.

Orlandi, P.: Siti di interesse minerario e mineralogico del territorio della Provincia di Pisa, Piano Territoriale di Coordinamento approvato con Deliberazione di Consiglio Provinciale n. 100 del 27/07/2006, 397 pp., 2006.

Parzych, A. E.: Accumulation of chemical elements by organs of Sparganium erectum $\mathrm{L}$. and their potential use in phytoremediation process, J. Environ. Eng., 17, 89-100, 2016.

Paz-Ferreiro, J., Lu, H., Fu, S., Méndez, A., and Gascó, G.: Use of phytoremediation and biochar to remediate heavy metal polluted soils: a review, Solid Earth, 5, 65-75, doi:10.5194/se-5-65-2014, 2014.

Prasad, M. N. V. and Freitas, H.: Metal hyperaccumulation in plants - Biodiversity prospecting for phytoremediation technology, Electron. J. Biotechnol., 6, 285-321, 2003.

Ramírez-Rodríguez, V., López-Bucio, J., and Herrera-Estrella, L.: Chapter 6. Adaptive Responses in Plants to Nonoptimal Soil pH, in: Plant Abiotic Stress, Blackwell Publishing, Oxford, UK, 145170, 2007.
Remon, E., Bouchardon, J. L., Le Guédard, M., Bessoule, J. J., Conord, C., and Faure, O.: Are plants useful as accumulation indicators of metal bioavailabity?, Environ. Pollut., 175, 1-7, 2013.

Sáez, R., Pascual, E., Toscano, M., and Almodóvar, G. R.: The Iberian type of volcano-sedimentary massive sulphide deposits, Miner. Deposita, 34, 549-570, 1999.

Salomons, W.: Environmental impact of metals derived from mining activities: Processes, predictions, prevention, J. Geochem. Explor., 52, 5-23, 1995.

Singh, R., Singh, D. P., Kumar, N., Bhargava, S. K., and Barman, S. C.: Accumulation and translocation of heavy metals in soil and plants from fly ash contaminated area, J. Environ. Biol., 31, 421-430, 2010.

Sobek, A. A., Schuller, W. A., Freeman, J. R., and Smith, R. M.: Field and laboratory methods applicable to overburden and minesoils, EPA 600/2-78-054, 203 pp., 1978.

Stefanowicz, A. M., Stanek, M., Woch, M. W., and Kapusta, P.: The accumulation of elements in plants growing spontaneously on small heaps left by the historical $\mathrm{Zn}-\mathrm{Pb}$ ore mining, Environ. Sci. Pollut. Res. Int., doi:10.1007/s11356-015-5859-7, 2015.

Tamás, J. and Kovács, E.: Vegetation Pattern and Heavy Metal Accumulation at a Mine Tailing at Gyöngyösoroszi, Hungary, Z. Naturforsch., 60C, 362-367, 2005.

Tomaškin, J., Tomaškinová, J., Kmeťová, J., and Drimal, M.: The Concentration of Heavy Metals in Grassland Ecosystems of the Central Slovakia National Parks, Carpath. J. Earth Env., 8, 3540, 2013.

Vamerali, T., Bandiera, M., and Mosca, G.: Field crops for phytoremediation of metal- contaminated land. A review, Environ. Chem. Lett., 8, 1-17, 2010.

VanReeuwijk, L. P.: Procedures for soil analysis. International soil reference and information centre (ISRIC) a FAO OSN, Technical Report, 9, Wageningen, Netherland, 4.1., 1995.

Verbruggen, N. and Hermans, C.: Physiological and molecular responses to magnesium nutritional imbalance in plants, Plant Soil, 368, 87-99, 2013.

Viehweger, K.: How plants cope with heavy metals, Bot. Stud., 55, 35 pp., 2014 